\title{
Molecular Alterations in Sporadic Primary Hyperparathyroidism
}

\author{
Maria Inês Alvelos, ${ }^{1,2}$ Maria Mendes, ${ }^{1,3}$ and Paula Soares ${ }^{1,4,5}$ \\ ${ }^{1}$ Institute of Molecular Pathology and Immunology of the University of Porto (IPATIMUP), 4200-465 Porto, Portugal \\ ${ }^{2}$ Faculty of Engineering of the University of Porto (FEUP), 4200-465 Porto, Portugal \\ ${ }^{3}$ Abel Salazar Biomedical Sciences Institute, University of Porto, 4099-003 Porto, Portugal \\ ${ }^{4}$ Faculty of Medicine, University of Porto (FMUP), 4200-319 Porto, Portugal \\ ${ }^{5}$ Cancer Biology Group, IPATIMUP, Rua Dr. Roberto Frias, s/n, 4200-465 Porto, Portugal
}

Correspondence should be addressed to Paula Soares, psoares@ipatimup.pt

Received 15 April 2011; Revised 3 July 2011; Accepted 11 July 2011

Academic Editor: Ilana Zalcberg Renault

Copyright (C) 2011 Maria Inês Alvelos et al. This is an open access article distributed under the Creative Commons Attribution License, which permits unrestricted use, distribution, and reproduction in any medium, provided the original work is properly cited.

Primary hyperparathyroidism (PHPT) is a frequent endocrine disorder characterized by an excessive autonomous production and release of parathyroid hormone (PTH) by the parathyroid glands. This endocrinopathy may result from the development of a benign lesion (adenoma or hyperplasia) or from a carcinoma. Most of the PHPT cases occur sporadically; however, approximately $10 \%$ of the patients present a familial form of the disease. The molecular mechanisms underlying the pathogenesis of sporadic PHPT are incompletely understood, even though somatic alterations in MEN1 gene and CCND1 protein overexpression are frequently observed. The MEN1 gene is mutated in about $30 \%$ of the parathyroid tumours and the protooncogene CCND1 is implicated in parathyroid neoplasia by rearrangements, leading to an overexpression of CCND1 protein in parathyroid cells. The aim of this work is to briefly update the molecular alterations underlying sporadic primary hyperparathyroidism.

\section{Introduction}

One of the multiple implications of multicellularity is that all parts of a body must be able to communicate with each other, in order to maintain homeostasis. The communication between different parts of an organism is essential for an appropriate response to internal and external environmental stimuli. The endocrine system, through the production, and release of hormones, is a key element for the establishment and maintenance of such regulation [1].

The parathyroid glands are the endocrine organs responsible for regulating calcium levels by producing a hormone, the parathyroid hormone (PTH), released directly into the blood [2] that regulates calcium levels acting at various organs.

Calcium plays a fundamental role in controlling the neuromuscular activity, the blood clotting process, bone structure, and integrity of cell signaling. The levels of ionized calcium in bloodstream are maintained by a complex hormonal mechanism, involving three main systems: gastrointestinal system, bone, and kidney $[3,4]$.
Primary hyperparathyroidism is a common endocrinopathy characterized by an inappropriate oversecretion of PTH. High PTH levels lead to a hypercalcemic state affecting different organs and systems such as bones and kidneys and cardiovascular, gastrointestinal, and nervous systems $[5,6]$.

The incidence of PHPT is estimated as 25 cases per 100000 individuals, and the main risk factors are older age, female gender, and exposure to cervical irradiation $[7,8]$.

This pathological condition, in 80 to $85 \%$ of the cases, is due to a parathyroid adenoma (uniglandular disease), followed by 15 to $20 \%$ of cases arising due to hyperplasia (multiglandular disease) and rarely, in 2 to $5 \%$ of cases, can be caused by a carcinoma [4].

Most of the PHPT cases belong to sporadic forms of the pathology, but about 10\% of the cases are familial forms [7].

Germline genetic alterations in MEN1 (multiple endocrine neoplasia type 1) gene are associated with PHPT in the context of MEN1 syndrome, and mutations in HRPT2 (hyperparathyroidism 2) gene are associated with HPT-JT (Hyperparathyroidism-Jaw tumor) familial syndrome. The development of PHPT in the context of MEN2 (multiple 
TABLE 1: Summary of the molecular alterations associated with familial and sporadic parathyroid tumors.

\begin{tabular}{|c|c|c|c|c|c|}
\hline & MEN1 $[20,50-52]$ & $\begin{array}{c}\text { CCND1 } \\
{[31,53-55]}\end{array}$ & HRPT2 [13, 56-58] & RET [48] & $\operatorname{CaSR}[49,59-61]$ \\
\hline Germline mutations & $\begin{array}{c}\text { Inactivating } \\
\text { mutations, LOH }\end{array}$ & - & $\begin{array}{l}\text { Inactivating } \\
\text { mutations, LOH }\end{array}$ & $\begin{array}{l}\text { Activating } \\
\text { mutations }\end{array}$ & $\begin{array}{c}\text { Inactivating } \\
\text { mutations }\end{array}$ \\
\hline (Familial syndrome) & (MEN1) & & (HPT-JT) & (MEN2A) & (NSHPT/FHH) \\
\hline \multicolumn{6}{|l|}{ Benign } \\
\hline Somatic mutations & $\begin{array}{l}\text { Inactivating } \\
\text { mutations, LOH }\end{array}$ & $\begin{array}{l}\text { Activating Inv (11) } \\
\quad(\mathrm{p} 15 ; \mathrm{q} 13)\end{array}$ & $\begin{array}{l}\text { Inactivating } \\
\text { mutations }\end{array}$ & $\mathrm{N}$ & $\mathrm{N}$ \\
\hline $\begin{array}{l}\text { Prevalence of somatic } \\
\text { alteration }\end{array}$ & 20 to $30 \%$ & $\sim 5 \%$ & 2 to $4 \%$ & - & - \\
\hline $\begin{array}{l}\text { Protein expression } \\
(\%)\end{array}$ & $\begin{array}{l}\text { Downregulation } \\
(20 \text { to } 40 \%)\end{array}$ & $\begin{array}{l}\text { Overexpression ( } 30 \\
\text { to } 40 \%)\end{array}$ & $\begin{array}{l}\text { Downregulation } \\
(\mathrm{ND})\end{array}$ & ND & $\begin{array}{l}\text { Downregulation } \\
\text { (Up to } 90 \%)\end{array}$ \\
\hline \multicolumn{6}{|l|}{ Malignant } \\
\hline Somatic mutations & Inactivating & ND & $\begin{array}{l}\text { Inactivating } \\
\text { mutations, LOH }\end{array}$ & $\mathrm{N}$ & ND \\
\hline $\begin{array}{l}\text { Prevalence of somatic } \\
\text { alteration }\end{array}$ & $\sim 13 \%$ & ND & 70 to $100 \%$ & - & - \\
\hline $\begin{array}{l}\text { Protein expression } \\
(\%)\end{array}$ & ND & $\begin{array}{l}\text { Overexpression } \\
\quad(\sim 90 \%)\end{array}$ & $\begin{array}{c}\text { Downregulation/loss } \\
\text { of expression } \\
(70 \text { to } 100 \%)\end{array}$ & ND & $\begin{array}{l}\text { Downregulation } \\
\quad(\sim 30 \%)\end{array}$ \\
\hline
\end{tabular}

$\mathrm{N}$ : negative; ND: not determined.

endocrine neoplasia type 2) syndrome, specifically in the variant MEN2A, is associated with genetic alterations in the RET (rearranged during transfection) gene. Homozygous or heterozygous mutations in CaSR (Calcium Sensing Receptor) gene are the source of NSHPT (neonatal severe hyperparathyroidism) and $\mathrm{FHH}$ (familial hypercalcemic hypercalciuric), respectively $[9,10]$.

Although, the genetic alterations associated with familial forms are well known, the genetic alterations underlying sporadic forms are far from being understood. The molecular alterations that are established as being characteristic of sporadic benign parathyroid tumor are genetic alterations in the MEN1 gene (20 to 30\% cases) and Cyclin D1 protein overexpression (30 to $40 \%$ of cases) [11, 12]. Parathyroid carcinomas are strongly associated with somatic HRPT2 mutations [13].

1.1. The Role of MEN1 Gene in PHPT. The MEN1 tumor suppressor gene was identified in 1997 as the gene responsible for the autosomal dominant syndrome characterized by tumors of endocrine pancreas, the anterior pituitary and parathyroid glands, the MEN1 syndrome [14]. Apart from being involved in the mentioned familial syndrome, somatic mutations of MEN1 gene are also implicated in the development of sporadic parathyroid tumors [15].

The MEN1 gene is located on chromosome 11 (band 11q13), consists of 10 exons (with 9 coding exons), and encodes a protein of 610 amino acids called menin that is ubiquitously expressed, at all stages of development [16]. The transcript of MEN1 gene is a $2.8 \mathrm{~Kb}$ mRNA but six more alternative transcripts have been reported, although none of them interferes with the coding region revealing variations of the $5^{\prime}$ translated region only [17]. Despite the high degree of conservation among metazoan, menin does not reveal motifs of known function and has no similarity with any other known protein [18].

Tumors of MEN1 patients usually reveal the presence of a germline mutation followed by a somatic alteration such as loss of heterozygosity ( $\mathrm{LOH})$ or inactivating mutation, as predicted by the model of Knudson, pointing to MEN1 gene as a very good example of a classical tumor suppressor gene [19].

About $30 \%$ of sporadic parathyroid tumors show MEN1 gene mutations (see Table 1). These somatic mutations, similarly to what happen with the germline mutations, are spread throughout the coding region. About $40 \%$ of these mutations are frameshift, $29 \%$ are missense mutations, $18 \%$ are nonsense, $7 \%$ occur in splice sites, and $6 \%$ are deletions or insertions in-frame. Sporadic parathyroid tumors harboring MEN1 gene somatic mutations frequently evidence $\mathrm{LOH}$ on chromosome region 11q13 [20]. Somatic inactivating mutations in this gene have also been identified in other types of tumors, namely, in neuroendocrine tumours such as gastrinomas, insulinomas, lung carcinoids, and pituitary tumors showing a similar loss of function mechanism promoting tumorigenesis [21-23].

From Drosophila to humans, menin is conserved but is absent in C.elegans and yeast [24]. Subcellular localization studies evidence that the protein has predominantly a nuclear localization and possesses two nuclear localization signals (NLSs) that should be essential for its role in regulation of gene transcription [25]. Menin has been reported to interact with a broad spectrum of proteins involved in regulation of transcription by coordinating chromatin remodeling, genome stability, cell division, and proliferation $[26,27]$. 
Recently, it was demonstrated in vitro that menin acts as a scaffold and inhibits $\mathrm{AKT} / \mathrm{PKB}$ activation by regulating its cellular localization, since it hampers the transition from the cytoplasm to the membrane, required to its activation [28].

The clinical relevance of pathways and molecular mechanisms in which menin is involved remain to be clarified.

Most of the MEN1 gene mutations will lead to a premature stop codon, giving rise to a truncated protein. Frequently this truncated menin may have lost, at least one of its NLS, compromising the protein function, regarding their role of driving the protein to the nucleus, but also by coordinating the regulation of expression of menin target genes [25].

Menin protein can function as suppressor of transcription, because this protein is able to bind a family of transcription factors such as AP-1/Jun-Fos family, and it is also associated with a histone methyltransferase (HMT) complex leading to an increased expression of cyclin-dependent kinase inhibitors (CDKIs) and consequently suppressing cell growth $[29,30]$.

1.2. The Role of Cyclin D1 Protein in PHPT. The gene encoding cyclin D1, CCND1, located in chromosome 11q13, was initially designated PRAD1 (parathyroid adenomatosis 1) since it was cloned from DNA from a parathyroid adenoma. In 1989, Arnold and colleagues found a genetic rearrangement in a parathyroid adenoma, this rearrangement, inv (11) (p15; q13), positions the 5' PTH gene regulatory region (located in 11p15) adjacent to the CCDN1 gene leading to the overexpression of cyclin D1 protein [31]. The increased expression of cyclin D1 promotes the transcription of genes required for DNA synthesis and cell cycle progression.

Several studies show the overexpression of cyclin D1 in $20-40 \%$ of parathyroid tumors (see Table 1), even though they do not demonstrate the presence of the rearrangement, pointing to the presence of other molecular abnormalities leading to an overexpression of this cell cycle regulator [32].

The pathogenic role of this protein was assessed through studies in transgenic mice overexpressing cyclin D1 in parathyroid. These mice were created to model the genetic rearrangement found in human parathyroid tumors [33]. In this model, the overexpression of this cell cycle regulator leads to hyperplasic parathyroid glands, with increased cell proliferation, retaining their capacity of hormone production [34].

1.3. Parathyroid Carcinoma and CDC73/HRPT2. In 2002, germline mutations in the tumor suppressor gene hyperparathyroidism 2 (HRPT2) were described by Carpten et al. as being responsible for the HPT-JT familial syndrome [13].

HRPT2 gene is located at 1q25-q31 and encodes a $60 \mathrm{kDa}$ nuclear protein named parafibromin that has been shown to be a member of the polymerase-associated factor (PAF1) complex involved in gene transcription regulation by histone ubiquitination and methylation $[35,36]$.

Additionally, parafibromin suppresses tumor growth by inducing apoptosis, inhibiting G1 to $\mathrm{S}$ phase transition, regulating Wnt canonical pathway, and also regulating gene expression by direct binding of promoter regions, being therefore expected that loss of parafibromin will lead to enhanced cellular proliferation [37-40].

The loss of parafibromin as a molecular marker of parathyroid carcinoma was first reported by Tan and colleagues in 2004. These authors noted that loss of parafibromin nuclear staining had a high sensitivity and specificity for the definitive diagnosis of parathyroid carcinoma and their results were confirmed by other groups [41, 42].

Despite its specificity, other studies indicated that, although occurring more frequently in parathyroid carcinomas, loss of parafibromin nuclear staining can also occur in a small proportion of sporadic benign adenomas and therefore cannot be considered exclusive of malignancy. Curiously, these adenomas exhibit cystic features which are commonly observed in the HPT-JT syndrome [43]. Another important aspect is the fact that nuclear positivity cannot exclude the presence of HRPT2 mutation, once some tumors harboring missense mutations revealed weak nuclear positivity [44].

Given the low frequency of parathyroid carcinomas, these are commonly misdiagnosed in the clinical setting and the need of specific markers for this disease is fundamental to reduce potential false-negative cases [45]. Some studies assessed the role of additional molecular marker to complement parafibromin staining in the screening process, emerging the protein 9.5 (PGP9.5) encoded by the ubiquitin carboxyl-terminal esterase L1 (UCHL1), that was found to be upregulated in the majority of parathyroid carcinomas [46]. In contrast, the tumor suppressor adenomatous polyposis coli $(A P C)$ was found downregulated in carcinomas while benign lesions retain the expression [47].

In spite of these findings, the unequivocal diagnosis remains a challenge, and additional markers are likely to increase the knowledge and proper recognition of parathyroid carcinomas.

\section{The Role of Other Genes in PHPT}

The knowledge on the molecular bases of parathyroid tumorigenesis, particularly the sporadic variant, remains largely unknown. Some candidate genes have been studied because of their possible role in sporadic primary hyperparathyroidism development (see Table 1). Despite their involvement in familial forms, no somatic mutations have been found in RET and CaSR genes [48, 49].

Vitamin D receptor (VDR) has an important role in negatively controlling PTH secretion and parathyroid proliferation, thus representing a good target for this parathyroid pathological condition, but no mutations in either VDR gene or vitamin-D-activating enzyme were found in sporadic parathyroid tumors despite the evidence of the reduced expression in some series [62-65].

Abnormal Wnt signaling has been associated with many types of tumors, and deregulation of CTNNB1 as well as mutations of LRP5 coreceptor has been found in some series of parathyroid tumors. At variance, other studies pointed out that Wnt/beta-catenin signaling does not seem to contribute to the development of parathyroid tumors [66-68].

The existence of common molecular alterations among endocrine tumors and its proximity with MEN1 gene 
raised the hypothesis that SDH5 gene could be involved in parathyroid tumorigenesis, but no genetic alterations were found in this pathology [69].

Using techniques such as comparative genomic hybridization (CGH), various authors verified the presence of chromosome gains and losses in specific regions, suggesting the presence of unidentified oncogenes and tumor suppressor genes, which may have a role in parathyroid tumorigenesis. Chromosomal regions in $1 \mathrm{p}, 6 \mathrm{q}, 9 \mathrm{p}$, and $13 \mathrm{q}$ were found to be lost in benign and malignant parathyroid lesions, indicating these chromosomal regions as eventual carriers of novel tumor suppressor genes. Unknown oncogenes may be present in chromosomal regions of $9 q, 16 p$, and $19 p$, because several authors demonstrated gain in these loci, in parathyroid tumors [70-72].

Chromosomal imbalances have been recognized as a mechanism able to alter the expression of miRNAs. Corbetta and collaborators explored the miR expression profile in parathyroid carcinomas, since the expression of these small noncoding RNAs varies between cancer and normal cells. These authors went to verify differential expression among parathyroid carcinoma and normal tissue. By real-time PCR, it was observed that the overall miRNA expression could separate normal versus cancer tissue and four miRs (miR296, miR-139, miR-222, and miR-503) revealed differences between tumoural and normal parathyroid tissues [73]. Some genes such as human growth factor-regulated tyrosine kinase substrate (HGS) and p27/Kip1 are described as potential targets of these miRNAs but further information about the biological relevance of these findings is needed and might provide tools for identifying new diagnostic and therapeutic strategies $[74,75]$.

Most of the studies in parathyroid tumorigenesis field have been performed using genomics and immunohistochemical approaches $[53,76]$. Giusti and collaborators carried out comparative analysis to examine the changes in protein profile between adenomas and normal parathyroid tissue [77]. These authors verified the presence of 30 deregulated proteins in parathyroid adenomas, 22 of them being overexpressed when compared to normal parathyroid tissue [77]. Some of the identified proteins belong to the same functional class of the ones identified by Haven and coworkers when they preformed tissue microarrays for benign and malignant tumors [78]. Overall, these findings represent promising steps for the improvement of the knowledge about this pathology.

\section{Concluding Remarks}

Presently, alterations in MEN1 and CCND1 are still the main genetic alterations associated with the development of sporadic benign tumors (accounting for approximately 30\% of the cases). The HRPT2 gene is not only responsible for the HPT-JT syndrome but also mutated in the majority of parathyroid carcinomas.

A number of other candidate genes (due to their genomic localization, role in familial syndromes, and/or biological function) have been studied in parathyroid tumors, but without promising results.
Future goals include the identification of additional oncogenes and/or tumor suppressor genes in parathyroid lesions and understanding the molecular insights in the relationship between parathyroid proliferation and hormone regulation.

\section{Acknowledgments}

This study was supported by an IPG-UP Grant (IPG2007-32, with financial support from CGD) and by Portuguese Foundation for Science and Technology through project grant. IPATIMUP is an Associate Laboratory of the Portuguese Ministry of Science, Technology and Higher Education that is partially supported by the FCT.

\section{References}

[1] S. Hiller-Sturmhöfel and A. Bartke, "The endocrine system: an overview," Alcohol Research and Health, vol. 22, no. 3, pp. 153-164, 1998.

[2] R. Mihai and J. R. Farndon, "Parathyroid disease and calcium metabolism," The British Journal of Anaesthesia, vol. 85, no. 1, pp. 29-43, 2000.

[3] G. N. Hendy, "Molecular mechanisms of primary hyperparathyroidism," Reviews in Endocrine and Metabolic Disorders, vol. 1, no. 4, pp. 297-305, 2000.

[4] J. W. Suliburk and N. D. Perrier, "Primary hyperparathyroidism," The Oncologist, vol. 12, no. 6, pp. 644-653, 2007.

[5] A. W. Norman and S. Hurwitz, "The role of the vitamin D endocrine system in avian bone biology," Journal of Nutrition, vol. 123, supplement 2, pp. 310-316, 1993.

[6] S. Miedlich, K. Krohn, and R. Paschke, "Update on genetic and clinical aspects of primary hyperparathyroidism," Clinical Endocrinology, vol. 59, no. 5, pp. 539-554, 2003.

[7] E. D. Taniegra, "Hyperparathyroidism," The American Family Physician, vol. 69, no. 2, pp. 333-339, 2004.

[8] G. Ippolito, F. F. Palazzo, F. Sebag, and J. F. Henry, "Longterm follow-up after parathyroidectomy for radiation-induced hyperparathyroidism," Surgery, vol. 142, no. 6, pp. 819-822, 2007.

[9] G. Westin, P. Björklund, and G. Åkerström, "Molecular genetics of parathyroid disease," The World Journal of Surgery, vol. 33, no. 11, pp. 2224-2233, 2009.

[10] R. A. DeLellis, P. Mazzaglia, and S. Mangray, "Primary hyperparathyroidism: a current perspective," Archives of Pathology and Laboratory Medicine, vol. 132, no. 8, pp. 1251-1262, 2008.

[11] S. Uchino, S. Noguchi, M. Sato et al., "Screening of the MEN1 gene and discovery of germ-line and somatic mutations in apparently sporadic parathyroid tumors," Cancer Research, vol. 60, no. 19, pp. 5553-5557, 2000.

[12] Y. Tominaga, T. Tsuzuki, K. Uchida et al., "Expression of PRAD1/cyclin D1, retinoblastoma gene products, and Ki67 in parathyroid hyperplasia caused by chronic renal failure versus primary adenoma," Kidney International, vol. 55, no. 4, pp. 1375-1383, 1999.

[13] J. D. Carpten, C. M. Robbins, A. Villablanca et al., "HRPT2, encoding parafibromin, is mutated in hyperparathyroidismjaw tumor syndrome," Nature Genetics, vol. 32, no. 4, pp. 676680, 2002.

[14] I. Lemmens, J. M. Van De Ven Wim, K. Kas et al., "Identification of the multiple endocrine neoplasia type 1 (MEN1) gene," Human Molecular Genetics, vol. 6, no. 7, pp. 1177-1183, 1997. 
[15] C. Heppner, M. B. Kester, S. K. Agarwal et al., "Somatic mutation of the MEN1 gene in parathyroid tumours," Nature Genetics, vol. 16, no. 4, pp. 375-378, 1997.

[16] S. C. Guru, J. S. Crabtree, K. D. Brown et al., "Isolation, genomic organization, and expression analysis of Men1, the murine homolog of the MEN1 gene," Mammalian Genome, vol. 10, no. 6, pp. 592-596, 1999.

[17] S. Khodaei-O’Brien, B. Zablewska, M. Fromaget, L. Bylund, G. Weber, and P. Gaudray, "Heterogeneity at the 5'-end of MEN1 transcripts," Biochemical and Biophysical Research Communications, vol. 276, no. 2, pp. 508-514, 2000.

[18] S. C. Guru, N. B. Prasad, E. J. Shin et al., "Characterization of a MEN1 ortholog from Drosophila melanogaster," Gene, vol. 263, no. 1-2, pp. 31-38, 2001.

[19] A. A. Pannett and R. V. Thakker, "Somatic mutations in MEN type 1 tumors, consistent with the Knudson "two-hit" hypothesis," Journal of Clinical Endocrinology and Metabolism, vol. 86, no. 9, pp. 4371-4374, 2001.

[20] M. C. Lemos and R. V. Thakker, "Multiple endocrine neoplasia type 1 (MEN1): analysis of 1336 mutations reported in the first decade following identification of the gene," Human Mutation, vol. 29, no. 1, pp. 22-32, 2008.

[21] Z. Zhuang, A. O. Vortmeyer, S. Pack et al., "Somatic mutations of the MEN1 tumor suppressor gene in sporadic gastrinomas and insulinomas," Cancer Research, vol. 57, no. 21, pp. 46824686, 1997.

[22] L. V. Debelenko, E. Brambilla, S. K. Agarwal et al., "Identification of MEN1 gene mutations in sporadic carcinoid tumors of the lung," Human Molecular Genetics, vol. 6, no. 13, pp. 22852290, 1997.

[23] Z. Zhuang, S. Z. Ezzat, A. O. Vortmeyer et al., "Mutations of the MEN1 tumor suppressor gene in pituitary tumors," Cancer Research, vol. 57, no. 24, pp. 5446-5451, 1997.

[24] G. M. Rubin, M. D. Yandell, J. R. Wortman et al., "Comparative genomics of the eukaryotes," Science, vol. 287, no. 5461, pp. 2204-2215, 2000.

[25] P. La, A. Desmond, Z. Hou, A. C. Silva, R. W. Schnepp, and X. Hua, "Tumor suppressor menin: the essential role of nuclear localization signal domains in coordinating gene expression," Oncogene, vol. 25, no. 25, pp. 3537-3546, 2006.

[26] T. Tsukada, Y. Nagamura, and N. Ohkura, "MEN1 gene and its mutations: basic and clinical implications," Cancer Science, vol. 100, no. 2, pp. 209-215, 2009.

[27] K. M. Dreijerink, R. A. Varier, O. Van Beekum et al., "The multiple endocrine neoplasia type 1 (MEN1) tumor suppressor regulates peroxisome proliferator-activated receptor gammadependent adipocyte differentiation," Molecular and Cellular Biology, vol. 29, no. 18, pp. 5060-5069, 2009.

[28] Y. Wang, A. Ozawa, S. Zaman et al., "The tumor suppressor protein menin inhibits AKT activation by regulating its cellular localization," Cancer Research, vol. 71, no. 2, pp. 371382, 2011.

[29] S. K. Agarwal, S. C. Guru, C. Heppner et al., "Menin interacts with the AP1 transcription factor JunD and represses JunDactivated transcription," Cell, vol. 96, no. 1, pp. 143-152, 1999.

[30] T. A. Milne, C. M. Hughes, R. Lloyd et al., "Menin and MLL cooperatively regulate expression of cyclin-dependent kinase inhibitors," Proceedings of the National Academy of Sciences of the United States of America, vol. 102, no. 3, pp. 749-754, 2005.

[31] A. Arnold, H. G. Kim, R. D. Gaz et al., "Molecular cloning and chromosomal mapping of DNA rearranged with the parathyroid hormone gene in a parathyroid adenoma," Journal of Clinical Investigation, vol. 83, no. 6, pp. 2034-2040, 1989.
[32] E. D. Hsi, L. R. Zukerberg, W. I. Yang, and A. Arnold, "Cyclin D1/PRAD1 expression in parathyroid adenomas: an immunohistochemical study," Journal of Clinical Endocrinology and Metabolism, vol. 81, no. 5, pp. 1736-1739, 1996.

[33] Y. Imanishi, Y. Hosokawa, K. Yoshimoto et al., "Primary hyperparathyroidism caused by parathyroid-targeted overexpression of cyclin d1 in transgenic mice," Journal of Clinical Investigation, vol. 107, no. 9, pp. 1093-1102, 2001.

[34] S. M. Mallya, J. J. Gallagher, Y. K. Wild et al., "Abnormal parathyroid cell proliferation precedes biochemical abnormalities in a mouse model of primary hyperparathyroidism," Molecular Endocrinology, vol. 19, no. 10, pp. 2603-2609, 2005.

[35] O. Rozenblatt-Rosen, C. M. Hughes, S. J. Nannepaga et al., "The parafibromin tumor suppressor protein is part of a human Paf1 complex," Molecular and Cellular Biology, vol. 25, no. 2, pp. 612-620, 2005.

[36] K. Chaudhary, S. Deb, N. Moniaux, M. P. Ponnusamy, and S. K. Batra, "Human RNA polymerase II-associated factor complex: dysregulation in cancer," Oncogene, vol. 26, no. 54, pp. 7499-7507, 2007.

[37] L. Lin, M. Czapiga, L. Nini, J. H. Zhang, and W. F. Simonds, "Nuclear localization of the parafibromin tumor suppressor protein implicated in the hyperparathyroidism-jaw tumor syndrome enhances its proapoptotic function," Molecular Cancer Research, vol. 5, no. 2, pp. 183-193, 2007.

[38] C. Zhang, D. Kong, M. H. Tan et al., "Parafibromin inhibits cancer cell growth and causes G1 phase arrest," Biochemical and Biophysical Research Communications, vol. 350, no. 1, pp. 17-24, 2006.

[39] C. Mosimann, G. Hausmann, and K. Basler, "Parafibromin/Hyrax activates Wnt/Wg target gene transcription by direct association with beta-catenin/Armadillo," Cell, vol. 125, no. 2, pp. 327-341, 2006.

[40] P. Wang, M. R. Bowl, S. Bender et al., "Parafibromin, a component of the human PAF complex, regulates growth factors and is required for embryonic development and survival in adult mice," Molecular and Cellular Biology, vol. 28, no. 9, pp. 2930-2940, 2008.

[41] F. Cetani, E. Ambrogini, P. Viacava et al., "Should parafibromin staining replace HRTP2 gene analysis as an additional tool for histologic diagnosis of parathyroid carcinoma?" The European Journal of Endocrinology, vol. 156, no. 5, pp. 547554, 2007.

[42] M. H. Tan, C. Morrison, P. Wang et al., "Loss of parafibromin immunoreactivity is a distinguishing feature of parathyroid carcinoma," Clinical Cancer Research, vol. 10, no. 19, pp. 66296637, 2004.

[43] C. Juhlin, C. Larsson, T. Yakoleva et al., "Loss of parafibromin expression in a subset of parathyroid adenomas," EndocrineRelated Cancer, vol. 13, no. 2, pp. 509-523, 2006.

[44] A. J. Gill, A. Clarkson, O. Gimm et al., "Loss of nuclear expression of parafibromin distinguishes parathyroid carcinomas and hyperparathyroidism-jaw tumor (HPT-JT) syndromerelated adenomas from sporadic parathyroid adenomas and hyperplasias," The American Journal of Surgical Pathology, vol. 30, no. 9, pp. 1140-1149, 2006.

[45] C. C. Juhlin and A. Höög, "Parafibromin as a diagnostic instrument for parathyroid carcinoma-lone ranger or part of the posse?" International Journal of Endocrinology, vol. 2010, Article ID 324964, 5 pages, 2010.

[46] V. M. Howell, A. Gill, A. Clarkson et al., "Accuracy of combined protein gene product 9.5 and parafibromin markers for immunohistochemical diagnosis of parathyroid carcinoma," 
Journal of Clinical Endocrinology and Metabolism, vol. 94, no. 2, pp. 434-441, 2009.

[47] C. C. Juhlin, F. Haglund, A. Villablanca et al., "Loss of expression for the Wnt pathway components adenomatous polyposis coli and glycogen synthase kinase 3-beta in parathyroid carcinomas," International Journal of Oncology, vol. 34, no. 2, pp. 481-492, 2009.

[48] S. Uchino, S. Noguchi, M. Nagatomo et al., "Absence of somatic RET gene mutation in sporadic parathyroid tumors and hyperplasia secondary to uremia, and absence of somatic MEN1 gene mutation in MEN2A-associated hyperplasia," Biomedicine and Pharmacotherapy, vol. 54, supplement 1, pp. 100s-103s, 2000.

[49] Y. Hosokawa, M. R. Pollak, E. M. Brown, and A. Arnold, "Mutational analysis of the extracellular $\mathrm{Ca}(2+)$-sensing receptor gene in human parathyroid tumors," Journal of Clinical Endocrinology and Metabolism, vol. 80, no. 11, pp. 3107-3110, 1995.

[50] S. Miedlich, K. Krohn, P. Lamesch, A. Müller, and R. Paschke, "Frequency of somatic MEN1 gene mutations in monoclonal parathyroid tumours of patients with primary hyperparathyroidism," The European Journal of Endocrinology, vol. 143, no. 1, pp. 47-54, 2000.

[51] M. M. Bhuiyan, M. Sato, K. Murao, H. Imachi, H. Namihira, and J. Takahara, "Expression of menin in parathyroid tumors," Journal of Clinical Endocrinology and Metabolism, vol. 85, no. 7, pp. 2615-2619, 2000.

[52] C. J. Haven, M. Van Puijenbroek, M. H. Tan et al., "Identification of MEN1 and HRPT2 somatic mutations in paraffin-embedded (sporadic) parathyroid carcinomas," Clinical Endocrinology, vol. 67, no. 3, pp. 370-376, 2007.

[53] A. Arnold, T. M. Shattuck, S. M. Mallya et al., "Molecular pathogenesis of primary hyperparathyroidism," Journal of Bone and Mineral Research, vol. 17, supplement 2, pp. N30N36, 2002.

[54] S. M. Mallya and A. Arnold, "Cyclin D1 in parathyroid disease," Frontiers in Bioscience, vol. 5, pp. D367-D371, 2000.

[55] M. A. Vasef, R. K. Brynes, M. Sturm, C. Bromley, and R. A. Robinson, "Expression of cyclin D1 in parathyroid carcinomas, adenomas, and hyperplasias: a paraffin immunohistochemical study," Modern Pathology, vol. 12, no. 4, pp. 412-416, 1999.

[56] F. Cetani, E. Pardi, S. Borsari et al., "Genetic analyses of the HRPT2 gene in primary hyperparathyroidism: germline and somatic mutations in familial and sporadic parathyroid tumors," Journal of Clinical Endocrinology and Metabolism, vol. 89, no. 11, pp. 5583-5591, 2004.

[57] T. M. Shattuck, S. Välimäki, T. Obara et al., "Somatic and germ-line mutations of the HRPT2 gene in sporadic parathyroid carcinoma," The New England Journal of Medicine, vol. 349, no. 18, pp. 1722-1729, 2003.

[58] L. J. Krebs, T. M. Shattuck, and A. Arnold, "HRPT2 mutational analysis of typical sporadic parathyroid adenomas," Journal of Clinical Endocrinology and Metabolism, vol. 90, no. 9, pp. 5015-5017, 2005.

[59] J. E. Witteveen, N. A. Hamdy, O. M. Dekkers et al., "Downregulation of CASR expression and global loss of parafibromin staining are strong negative determinants of prognosis in parathyroid carcinoma," Modern Pathology, vol. 24, no. 5, pp. 688-697, 2011.

[60] C. J. Haven, M. van Puijenbroek, M. Karperien, G. J. Fleuren, and H. Morreau, "Differential expression of the calcium sensing receptor and combined loss of chromosomes 1q and 11q in parathyroid carcinoma," Journal of Pathology, vol. 202, no. 1, pp. 86-94, 2004.

[61] S. Corbetta, G. Mantovani, A. Lania et al., "Calcium-sensing receptor expression and signalling in human parathyroid adenomas and primary hyperplasia," Clinical Endocrinology, vol. 52, no. 3, pp. 339-348, 2000.

[62] E. H. Samander and A. Arnold, "Mutational analysis of the vitamin D receptor does not support its candidacy as a tumor suppressor gene in parathyroid adenomas," Journal of Clinical Endocrinology and Metabolism, vol. 91, no. 12, pp. 5019-5021, 2006.

[63] K. Lauter and A. Arnold, "Analysis of CYP27B1, encoding 25hydroxyvitamin D-1alpha-hydroxylase, as a candidate tumor suppressor gene in primary and severe secondary/tertiary hyperparathyroidism," Journal of Bone and Mineral Research, vol. 24, no. 1, pp. 102-104, 2009.

[64] R. Kremer, I. Bolivar, D. Goltzman, and G. N. Hendy, "Influence of calcium and 1,25-dihydroxycholecalciferol on proliferation and proto-oncogene expression in primary cultures of bovine parathyroid cells," Endocrinology, vol. 125, no. 2, pp. 935-941, 1989.

[65] A. Szabo, J. Merke, E. Beier, G. Mall, and E. Ritz, "1,25(OH)2 vitamin D3 inhibits parathyroid cell proliferation in experimental uremia," Kidney International, vol. 35, no. 4, pp. 1049 1056, 1989.

[66] P. Björklund, D. Lindberg, G. Åkerström, and G. Westin, "Stabilizing mutation of CTNNB1/beta-catenin and protein accumulation analyzed in a large series of parathyroid tumors of Swedish patients," Molecular Cancer, vol. 7, article 53, 2008.

[67] F. Cetani, E. Pardi, C. Banti et al., "Beta-catenin activation is not involved in sporadic parathyroid carcinomas and adenomas," Endocrine-Related Cancer, vol. 17, no. 1, pp. 1-6, 2010.

[68] P. Björklund, G. Åkerström, and G. Westin, “An LRP5 receptor with internal deletion in hyperparathyroid tumors with implications for deregulated WNT/beta-catenin signaling," PLoS Medicine, vol. 4, no. 11, article e328, 2007.

[69] L. F. Starker, A. Delgado-Verdugo, R. Udelsman, P. Björklund, and T. Carling, "Expression and somatic mutations of SDHAF2 (SDH5), a novel endocrine tumor suppressor gene in parathyroid tumors of primary hyperparathyroidism," Endocrine, vol. 38, no. 3, pp. 397-401, 2010.

[70] N. Palanisamy, Y. Imanishi, P. H. Rao, H. Tahara, R. S. K. Chaganti, and A. Arnold, "Novel chromosomal abnormalities identified by comparative genomic hybridization in parathyroid adenomas," Journal of Clinical Endocrinology and Metabolism, vol. 83, no. 5, pp. 1766-1770, 1998.

[71] S. K. Agarwal, E. Schröck, M. B. Kester et al., "Comparative genomic hybridization analysis of human parathyroid tumors," Cancer Genetics and Cytogenetics, vol. 106, no. 1, pp. 30-36, 1998.

[72] J. L. García, J. C. Tardío, N. C. Gutiérrez et al., "Chromosomal imbalances identified by comparative genomic hybridization in sporadic parathyroid adenomas," The European Journal of Endocrinology, vol. 146, no. 2, pp. 209-213, 2002.

[73] S. Corbetta, V. Vaira, V. Guarnieri et al., "Differential expression of microRNAs in human parathyroid carcinomas compared with normal parathyroid tissue," Endocrine-Related Cancer, vol. 17, no. 1, pp. 135-146, 2010.

[74] T. Würdinger, B. A. Tannous, O. Saydam et al., "miR-296 regulates growth factor receptor overexpression in angiogenic endothelial cells," Cancer Cell, vol. 14, no. 5, pp. 382-393, 2008 . 
[75] R. Visone, L. Russo, P. Pallante et al., "MicroRNAs (miR)-221 and miR-222, both overexpressed in human thyroid papillary carcinomas, regulate p27Kip1 protein levels and cell cycle," Endocrine-Related Cancer, vol. 14, no. 3, pp. 791-798, 2007.

[76] P. J. Newey, M. R. Bowl, T. Cranston, and R. V. Thakker, "Cell division cycle protein 73 homolog (CDC73) mutations in the hyperparathyroidism-jaw tumor syndrome (HPT-JT) and parathyroid tumors," Human Mutation, vol. 31, no. 3, pp. 295-307, 2010.

[77] L. Giusti, F. Cetani, F. Ciregia et al., "A proteomic approach to study parathyroid glands," Molecular BioSystems, vol. 7, no. 3, pp. 687-699, 2011.

[78] C. J. Haven, V. M. Howell, P. H. C. Eilers et al., "Gene expression of parathyroid tumors: molecular subclassification and identification of the potential malignant phenotype," Cancer Research, vol. 64, no. 20, pp. 7405-7411, 2004. 

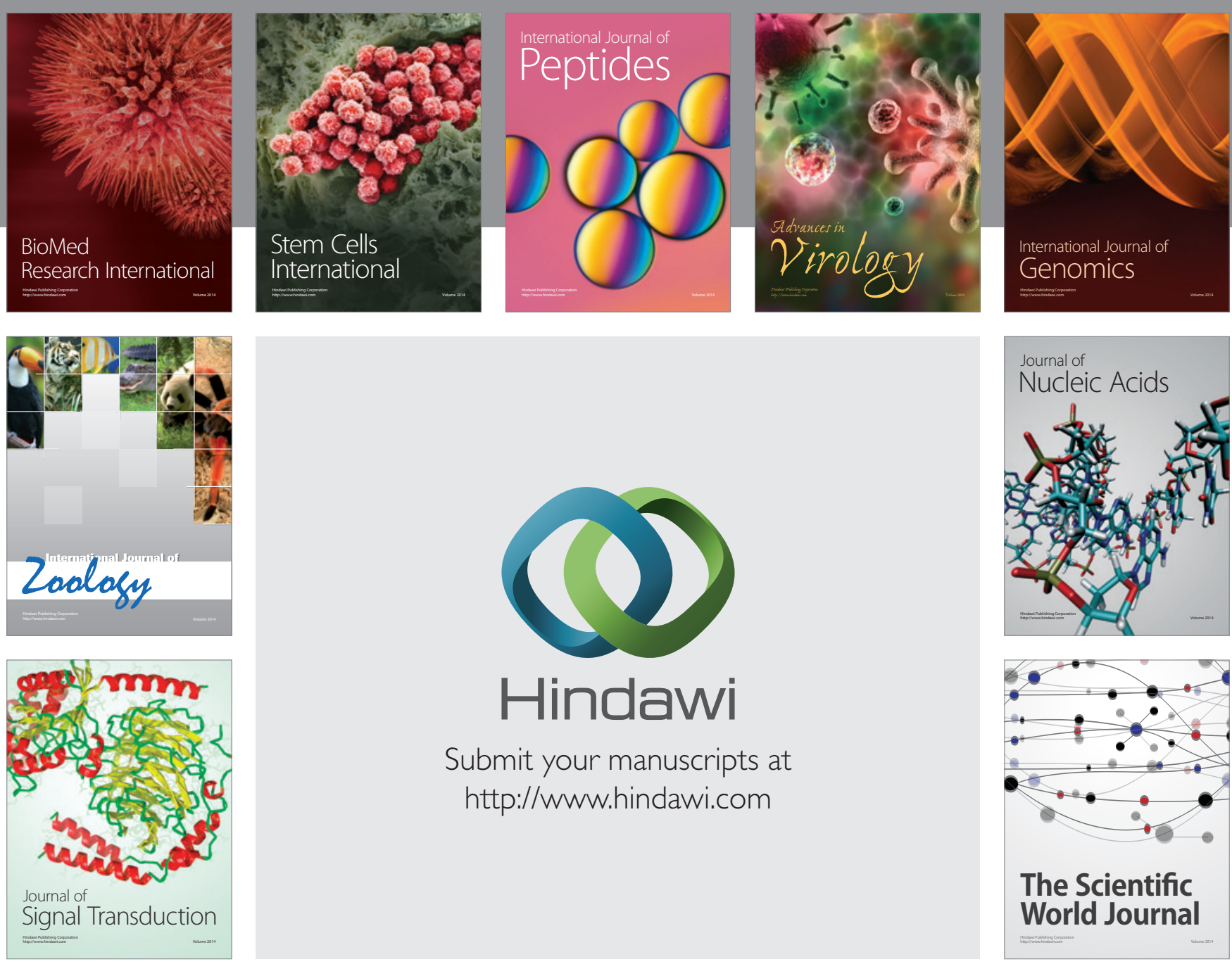

Submit your manuscripts at

http://www.hindawi.com
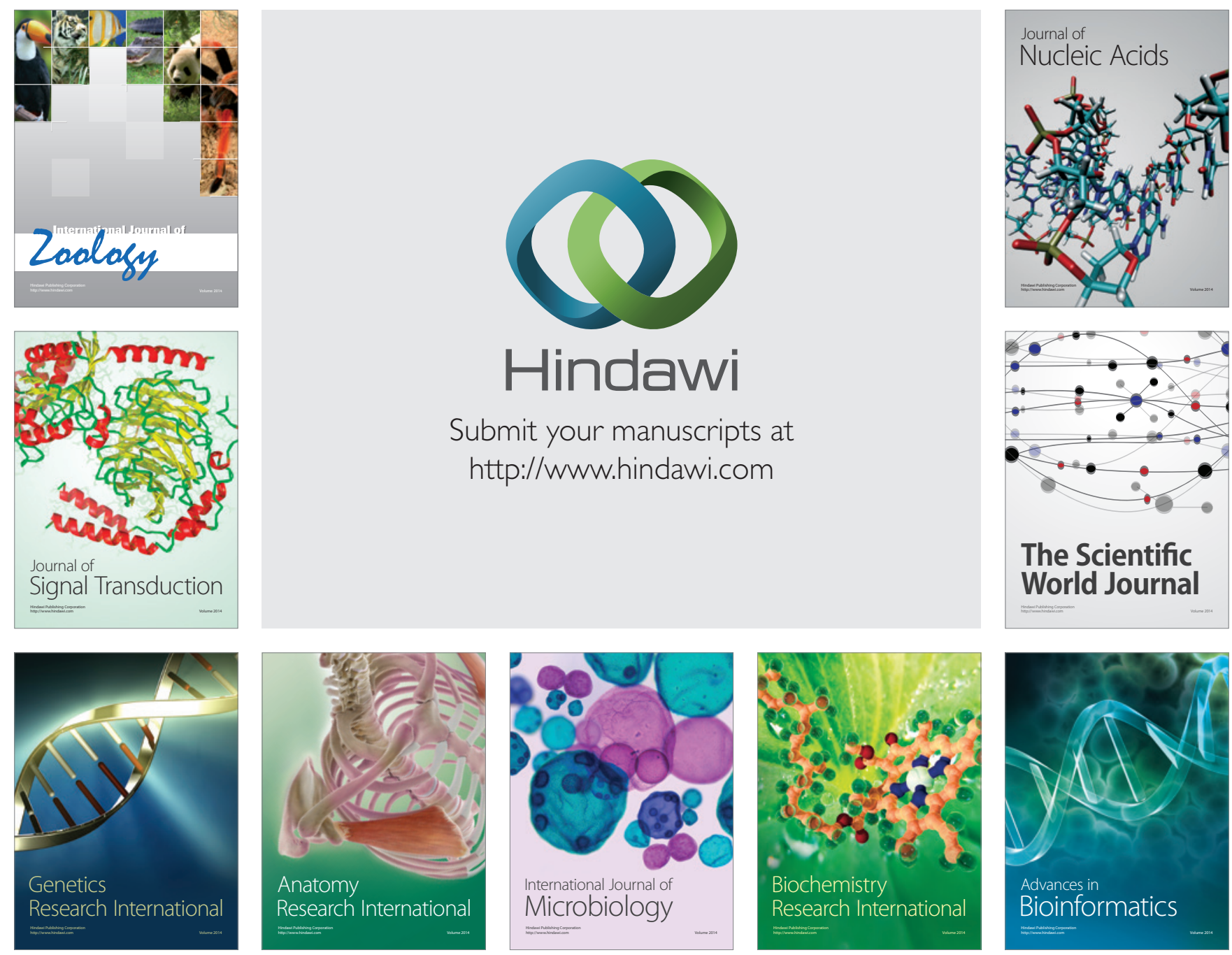

The Scientific World Journal
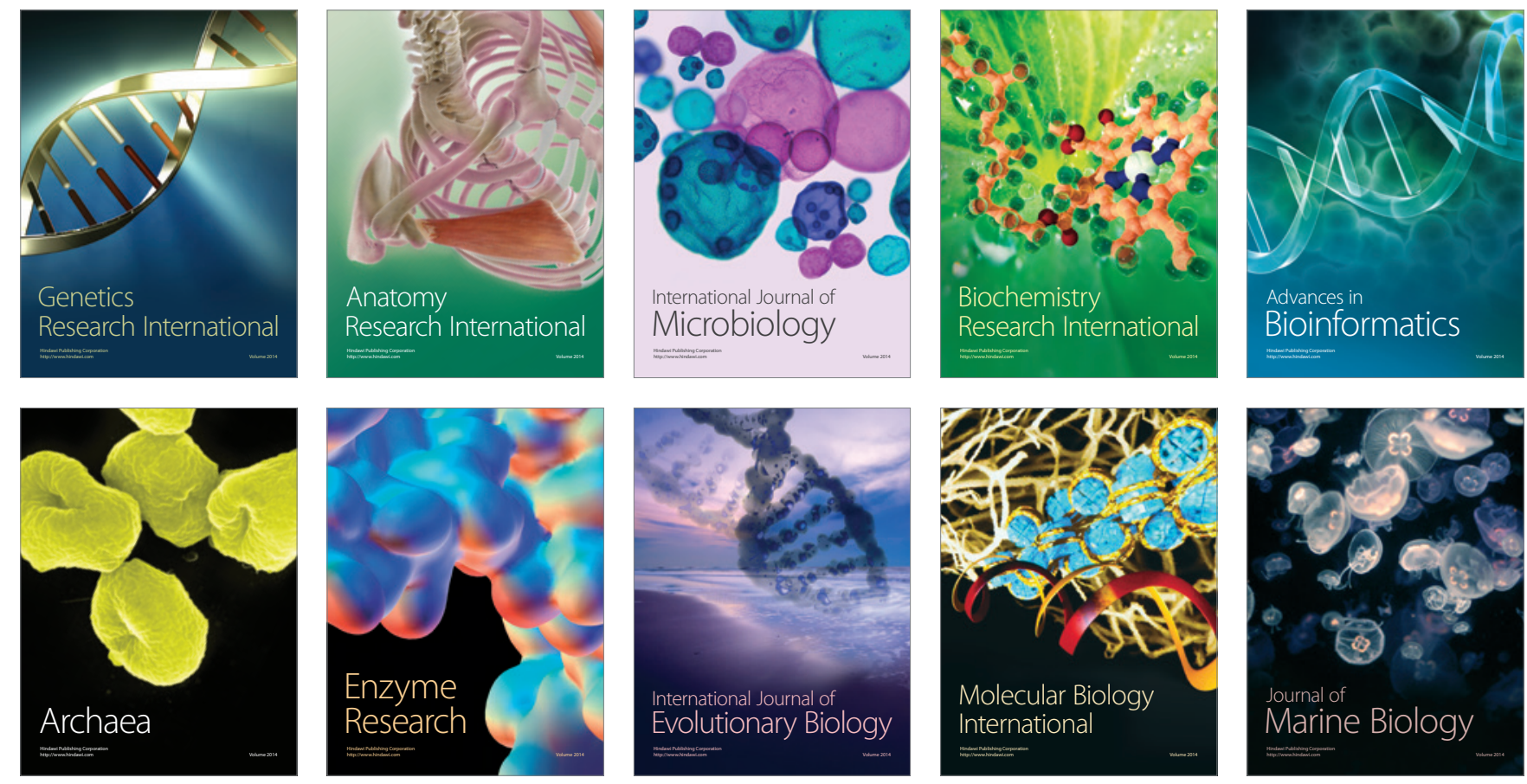